\title{
Reemergence of Policy Practice: A Journey Back to our Roots
}

\author{
Katharine V. Byers
}

\begin{abstract}
Many people and events have contributed to a renewed focus on policy practice in social work and social work education, culminating in the inclusion of policy practice as one of the ten core social work competencies in the 2008 Council on Social Work Education EPAS. Robert Schneider, founder of Influencing State Policy, was a key player in elevating policy practice, particularly at the state level, in light of the increasing devolution of social policy decision-making to the states. Other social workers and educators created opportunities for policy scholars and practitioners to collaborate, including Leon Ginsberg and the Policy Conference that he and others initiated. Now a new generation of policy practitioners will continue to educate social workers in policy practice skills in the pursuit of social justice.
\end{abstract}

Keywords: Policy practice, Influencing State Policy, teaching advocacy skills

This narrative reflects my own recollection and sense-making of our collective journey to bring policy practice back into the forefront of social work education. I have highlighted, in particular, the work of Robert L. Schneider, professor emeritus from Virginia Commonwealth University, who created Influencing State Policy, an organization providing resources and opportunities for the exchange of ideas about influencing policy at the state level. Bob has been a collaborative reviewer of this document, as one of the major actors in this history.

I remember it as if it were yesterday. The date is March 8, 1997, and the place is Chicago Illinois, site of the $45^{\text {th }}$ Annual Program Meeting of the Council on Social Work Education. To the casual observer, there was nothing especially unusual about this particular gathering of the profession's educators. There was the typical array of interesting sessions to be attended, old friends huddled over lunch to renew acquaintances, and colleagues engaged in conversations that promised new opportunities for collaborative scholarly activities, while others ventured out into the windy environs of Chicago to explore its many wonders. At 7:30 that evening, unlike most of my friends who were headed out for "a night on the town," I found myself sitting in a small hotel meeting room attending the first ever meeting of the then named National Committee for Educating (Social Work) Students to Influence State Policy and Legislation. Mary Katherine O'Connor, a friend and colleague from Virginia Commonwealth University, had told me her VCU colleague, Robert (Bob) Schneider, had called this meeting of social work policy folks to foster more state level advocacy in light of the devolution of policy making from the federal government to the states with the passage of the Personal Responsibility and Work Opportunity Act of 1996 (commonly referred to as Welfare Reform). I was not sure about going, but Mary Katherine had never led me astray so there I was. The 27 people who attended that first meeting, including the President and Executive Director of the National Association of Social Workers (NASW),

Katharine V. Byers, Ph.D., is Associate Professor and Director of the Indiana University School of Social Work's BSW program on the Bloomington, IN campus.

Copyright (C) 2014 Advances in Social Work Vol. 15 No. 1 (Spring 2014), 34-50 
enthusiastically embraced the idea of forming what is now called Influencing State Policy.

Fast forward to 2008 and the inclusion of policy practice as one of the ten core social work competencies identified in our CSWE Educational Policy and Accreditation Standards:

Educational Policy 2.1.8-Engage in policy practice to advance social and economic well-being and to deliver effective social work services.

Social work practitioners understand that policy affects service delivery, and they actively engage in policy practice. Social workers know the history and current structures of social policies and services; the role of policy in service delivery; and the role of practice in policy development. Social workers

analyze, formulate, and advocate for policies that advance social wellbeing; and

collaborate with colleagues and clients for effective policy action (CSWE, 2008, p. 6).

This elevation of policy practice as one of the ten core competencies was celebrated as a huge accomplishment by social workers, both inside and outside academia, who had long sought return to the policy practice roots of the profession. How did we get from 1997 when few social work educators were talking about policy practice to 2008 and the inclusion of policy practice as one of the core competencies?

In this article, I will discuss my perceptions and understanding of how the persistent efforts of Bob Schneider and others who shared his passion for the policy practice initiative ultimately led to its inclusion as one of the core social work competencies. During this reflective journey, I will attempt to capture some of the historical, ideological and political issues that surrounded this initiative. I will conclude with reflections from a recent discussion with Bob about the next steps needed to advance the field of policy practice as we "elders" pass the baton to the next generation of social workers and social work educators. Before we start, as in all narratives of this sort, it is helpful to set the context and look back at some of the historical underpinnings of policy practice in the social work profession.

\section{Historical Overview}

With the roots of our profession deeply embedded in the social reforms of the Progressive Era, it is no surprise that workers in both settlement houses and charity organization societies were engaged in what we currently refer to as policy practice activities. Jane Addams engaged in policy practice when she and other settlement house workers endeavored to improve the living conditions in the tenement neighborhoods where they lived and worked. Julia Lathrop, another settlement house worker, engaged in policy practice when she helped establish the first juvenile courts in Cook County, Illinois. Social workers such as Harry Hopkins, Frances Perkins, Grace and Edith Abbott, who also came out of the settlement house movement and worked at the community 
level, were engaged in policy practice when they shaped the New Deal policies of President Franklin D. Roosevelt to respond to the challenges of the Great Depression. Frances Perkins, as Secretary of Labor, was one of the primary architects of the Social Security Act and was particularly adamant that unemployment insurance be included as part of the law (Cummins, Byers, \& Pedrick, 2011).

Despite this rich early history in policy practice and advocacy, as social work sought greater professional recognition in the 1940's and 1950's, social workers placed less emphasis on policy practice and instead focused on the provision of mental health services. Later, in the 1960's, turning back to policy practice, social workers like Wilbur Cohen were involved in the development of the War on Poverty programs designed to bring resources and opportunities to low-income communities. Whitney Young, director of the National Urban League, was one of many social workers involved in the civil rights struggles of the 1960's and a major architect of the federally funded Project ENABLE initiative. Though social work leaders were engaged in important civil rights efforts, some worried about the depth of the engagement and commitment of the rank and file social workers in local agencies. Howard Gustafson, President of NASW at the time, after participating in the 1965 Selma to Montgomery March, reflected, "On the way back home, I tried to analyze what the civil rights struggle means to our Association...I was wondering whether social workers, and NASW in particular, are really prepared to act on social issues in their own communities and in their own Agencies" (NASW Foundation, n.d.).

Social workers were involved in many local community efforts to improve civil rights even if their names were not in the headlines or in the national news. They were the people in the crowd scenes. In addition, for those of us who "grew up" during the 1960's, the sit-ins, protests, marches, and door-to-door campaigns, both in the big cities of the North and the rural communities of the South, were pivotal in our own political and social justice development.

Raised in a family in which social activism was a way of life, advocacy on social justice issues has been a driving imperative throughout my life. As a high school student, I volunteered with the Kennedy Presidential campaign. Working the phone banks helped compensate for being too young to vote. As a college student, I marched regularly in civil rights protests in the Boston area. Between college and graduate school, concerned that skyrocketing rents were driving working families out of Cambridge, MA, where I lived, I knocked on tenement apartment doors to gather petition signatures as part of the (Marxist) Peace and Freedom Party's rent control campaign. Later, as an MSW student, it seemed only natural to participate in the protests of both students and welfare rights organizations at the 1969 National Conference on Social Welfare, well-documented in The Social Welfare Forum (National Conference on Social Welfare, 1969). Although the exact details of the pressing social justice issues of the time have faded from my memory, I recall vividly the disruptive impact our collective efforts had on that important annual meeting, with some specific memories returning when I read the official commentary on the events. All of these experiences made it eminently apparent to me, as a beginning social worker, that collective social action can indeed make a meaningful difference. These and more recent policy efforts are the examples I use to convince our 
contemporary students of the efficacy of their own policy efforts, as I am sure is the case for other social work policy faculty.

Many current faculty and older social workers witnessed this renewed commitment to the profession's core social justice mission during the tumultuous 60's. Despite some significant incremental changes in the law, progress on the ground was much slower to materialize. It was a long and arduous uphill battle that ultimately saw some of the original combatants opt for safer and more predictable career paths. For some of us, that passion for social justice continues to burn to this day with the same intensity that inspired us during those formative years.

In the 1970's and 1980's, much of social work advocacy energy was redirected toward establishing licensing laws in the states and developing clinical, rather than community, practice. The focus of the profession was on enhancing the status of clinical practice at the expense of furthering the community-based initiatives of the ' $60 \mathrm{~s}$. James Wolk (1981) found that social workers were no more politically active than average citizens in the country. Harry Specht and Mark Courtney (1994) even charged that social work had "abandoned its mission." In social work education, community organizing tracks in MSW programs started to decline as more social workers wanted to be "therapists." So how did we get from this "abandonment" to the inclusion of policy practice as one of the ten core competencies in social work? It seems like a huge leap in a little over ten years.

\section{The Shifting Political Winds and their Impact on Policy Practice}

The 1996 passage of the Personal Responsibility and Work Opportunity Act (Welfare Reform) served as a wake-up call to social workers and social work educators, both for its policies/guidelines and for the implications of shifting more involvement in social policy formulation and implementation to the state level. This devolution of policy making to the states provided both cautions and opportunities for social work advocates. The new federal law established Temporary Assistance to Needy Families (TANF) to replace the long established entitlement program, Aid to Families with Dependent Children (AFDC), with substantive changes designed to help single mothers become employed in the workforce within a two-year time limit, with very few exceptions. States were given greater latitude in setting eligibility guidelines and work requirements than had been the case under the former AFDC legislation. Ending the entitlement program, the policy goal was clearly to reduce the welfare rolls and government expenditures, not to reduce poverty. And, indeed, average earnings of those leaving the TANF rolls were below existing federal poverty levels (Stoesz, 1999).

Social workers and social work educators became concerned about the impact of TANF on the lives of low-come women and their families (Swigonski, 1996). Some academics turned their concern into a traditional outlet: conducting research on welfare reform implementation (Byers \& Pirog, 2003; Larrison, Nackerud, Lane-Crea, \& Robinson-Dooley, 2005). Others wrote policy pieces and critiques of the profession (Long, 2000; Mills, 1996). Abramovitz (1998) made recommendations for social workers

to recommit to their tradition of activism, noting, "Historically, a small group of social 
workers consistently kept the voice of change alive" (p. 524). Schneider and Netting (1999) framed devolution as a crossroads for social work, presenting a new opportunity to develop skills and commitment to influence policy. "Socializing practitioners, faculty, and students to a commitment to change state policy and engage in legislative processes is a continuing challenge," noted Schneider and Netting (1999, p. 354). Lens and Gibelman (2000) were particularly critical of social work's lack of involvement in welfare reform efforts, calling it a "failed opportunity to influence the course of public debate" (p. 611). Karger and Hernández (2004) made a case for a "renewed vision around the social justice mission of social work" (p. 51). A crescendo of voices advocating for an increased activist role for the social work profession seemed to be building.

A few social work educators started to take action in new and different directions. I will highlight five specific developments that contributed significantly to the restoration of policy practice as a core social work responsibility: the development of Influencing State Policy and its initiatives; the development of the annual Policy Conference; an increase in the number of policy courses in accredited social work program with the accompanying policy practice-focused textbooks to support those courses; revisions of the Code of Ethics with a renewed emphasis on advocacy; and. the feedback to CSWE about the importance of highlighting policy practice in the 2008 EPAS. We will look at each development separately, though many of the same actors were involved in each one so the developments influenced and intertwined with each other, creating an important synergistic effect.

\section{Influencing State Policy}

Bob Schneider was not new to political activism when he distributed flyers titled "The States Take Over Welfare Policy: Project to Prepare Students \& Faculty" inviting policy faculty, deans, directors, and interested social workers to meet that Saturday night in Chicago in 1997. As a 10-year member (including serving as Chair for 2 years) of the Governor's Advisory Board to the Virginia Department of Aging, he had become concerned about the 1994 effort by Governor George Allen to consolidate this agency with another state agency in the name of efficiency. Spearheaded by a spirited phone campaign, he was able to build a coalition that ultimately defeated the Governor's proposal (Jansson, 2011). When welfare reform was passed in 1996, Bob lamented that he was both troubled and disgusted with himself and the profession for not having much of a role in opposing Clinton's initiatives. "When I was on vacation and visiting the state capital of Olympia, Washington, it hit me. We needed a structure to increase our role in the states. We 'blew it' at the federal level and now we had a chance to shift to the states. Why not promote policy practice at the schools of social work that are in state capitals?" (Personal communication, December 30, 2013). When he got home, he realized that all social work programs have access to legislators, not just those in the state capitals, and so all programs should be involved.

But involved in what? From his own teaching, Bob knew that an experiential approach, getting students to actually talk with legislators about pending legislation, helped overcome the traditional reluctance and resistance that students bring to policy courses. Prior to this time, most social policies discussed in the social policy classes were 
federal in nature: Social Security, Veterans' benefits, Medicare, etc. Welfare reform changed the traditional federal-state partnership for many of the needs-based programs such as TANF, Food Stamps, and Medicaid, tilting the policy making power more toward the states. That change not only required new strategies, but also provided new opportunities for advocacy efforts. Bob wanted students to be able to make a difference in the states where they lived, worked, and went to school. He gained support from his Dean and ran his emerging ideas by colleagues at the national offices of CSWE and NASW. He took the fall to prepare for the spring meeting at CSWE's Annual Program Meeting and sent information about the meeting to all the social work deans to distribute to their policy faculty.

Bob came to the meeting on March 8, 1997, brimming with ideas and handouts on different colored papers. There was excitement in the air. Here were 27 faculty and professional leaders, most of whom shared his vision of an organization that could assist faculty with resources and incentives to get students involved in policy advocacy work. He had drafted a rationale, mission statement, goals, outcomes, objectives, potential products, bibliography, and ideas for student projects. I remember coming away from the meeting inspired and rejuvenated by the energy generated by both Bob's presentation and our brainstorming exchange as we generated even more ideas. And I had signed on to help, along with a number of others. We became friends and collaborators in that room that night because we shared this common passion for policy, a passion not always shared among our peers in social work education or our students.

Some of the people like David Dempsey, John McNutt, and Paul Stuart in the room that night were already known in social work policy circles for their writing, scholarly activity, and practice initiatives. Others, like Janet Dickinson, David Katz, Jim Kunz, Mary Katherine, and me, were younger faculty members, many of us just launching our careers in social work education. The rationale for ISP that Bob presented was one we could all embrace:

If social workers do not exert policy leadership, they allow other people with less commitment to the well-being of vulnerable and oppressed people to shape the human services delivery systems. Social workers need to enhance their credibility by making informed contributions to policy discourse in state capitals ("Purpose," 1997).

And so the mandate for ISP was set: to help faculty prepare social workers to assume these policy practice roles in advocacy work at the state level. We passed the hat (literally) in that first meeting to collect funds so Bob could continue his work in building the organization.

With Bob's guidance, indefatigable energy, and effective organizing strategies, Influencing State Policy grew from that "gang of 27" in Chicago to over 300 paid members at the $10^{\text {th }}$ anniversary celebration. Starting fall1997, each semester Bob distributed a newsletter, Influence, with reports and articles of interest to faculty, including state-by-state counts of how many students visited their state capitals to influence policy. A website was created (www.statepolicy.org) that included resources for teaching policy. With some grant support, Bob guided the development of six 30- 
minute videos highlighting different aspects of state policy making, including legislative advocacy, state budget making, and coalition building. The videos, initially on separate VHS tapes and then later combined on a DVD, came to faculty with the modest ISP membership fee. Live auctions were held at several conferences to raise funds for various ISP activities. In addition, during this time, Bob authored or was featured in a number of articles describing the importance of state policy work and the role of ISP (Schneider, 2002; Schneider, 2003; Schneider, 2004; Schneider \& Netting, 1999; "Students seek state clout," 1997).

Bob developed three contests to provide an opportunity for faculty to engage students in an experiential process of influencing state policy. Under faculty mentorship, he envisioned groups of students creating strategies to influence policy makers in their states on a particular policy. Two-page entries to the contests described the strategies the students used. The advocacy effort did not need to result in success: what was pivotal to the reviewers was that students learned from engaging in the process. The empowerment and sense of self-efficacy expressed in the essays were powerful: "We are inspired to continue being active in the legislative process because we received positive responses at our outreach events, and we discovered that we have the ability to influence change, that our voices will be heard, and even busy individuals will take a few minutes of their time to promote change" (Personal Communication, 2009). Annual contests at the BSW and MSW levels awarded cash prizes to both the students and the faculty member involved. Some schools used the funds to help support their own state Lobby Day events. A Ph.D. contest for doctoral students (later named in honor of Bob) granted awards to those researching a state policy related issue, thereby attempting to increase state policy research among young faculty. Contest winners were honored at a national social work education meeting, such as the Policy Conference and CSWE's APM.

On February 18, 2006, again in Chicago, we celebrated the tenth anniversary of ISP with a gala dinner. That year, there were over 800 people on the email list with 300 duespaying members. Seven organizations were helping to sponsor the annual contests. Five different videos about state policy making processes had been produced and distributed to members. Reported student visits to state capitals were 6000 to 7000 annually. Nine annual BSW and MSW student contests had been held with awards going to outstanding projects advocating on issues such as mental health budget increases, child welfare issues, immigration, and others. Five annual Ph.D. awards had been granted to doctoral students (R. Schneider, personal communication, 2006).

Since Bob's retirement and my assuming the Chair role, ISP has undergone some retrenchment. Funding has been tighter for programs and sponsors resulting in the reduction in the amounts of the cash prizes for the contests, but the quality of the student efforts in advocacy remains impressive. The email list has remained high, with over 1000 , but the number of dues paying members has dropped. Once faculty members receive the DVD, there seems to be less incentive to pay annual dues. At the most recent annual meeting in the fall of 2013, a slate of new officers, to replace the original Board of Advisors that Bob created, was elected to broaden the leadership and incorporate new ideas and energy. Most recently, resource lists for several state policy issues have been developed for distribution to faculty. We are exploring how we might maximize our 
Facebook page and other social media to engage more students and faculty. The webpage will be revamped soon and other media will be explored, including a wiki, to broaden participation and involvement of members. New energy and engagement of younger faculty will insure the future value of ISP.

\section{Development of the Policy Conference}

Summer in Charleston, South Carolina may not sound like an opportune time and place for social work educators to gather for what became affectionately known as "the Policy Conference." That first year, 1998, it was titled the Faculty Development Institute on Social Welfare Policy and Services, and sponsored by the University of South Carolina, NASW, and other groups. The Policy Conference was envisioned by organizers, including Leon Ginsberg in collaboration with Dave Dempsey from NASW's national office and others, as a small gathering of both the policy scholars/sages of the profession as well as younger faculty teaching policy. The description from the 2002 program registration materials captures the intent well:

This conference is designed to help prepare the social work profession to assume a greater role in influencing public social welfare policy by: 1) enhancing educators' skills in policy analysis and instructional methodologies; 2) becoming familiar with current advocacy and social action efforts and developing advocacy skills; 3) cultivating linkages among the education and practice communities; 4) expanding social workers' knowledge of the political system and how to work within it to further the objectives of the profession; and 5) enhancing skill and knowledge in the teaching and practice of social administration (The Policy Conference for Social Work Education and Practice, 2002).

I remember well my excitement when I saw the Call for Papers and my determination to attend. Can you imagine - a whole conference for people who were passionate about social welfare policy? I could not imagine a better way to spend a few days of my summer. My accepted presentation focused on ways to build more activist social workers through advocacy assignments in policy courses. A number of sessions highlighted welfare reform research. Those of us who attended that first Policy Conference and subsequent ones, whether in Charleston, Atlanta, or in Washington, D.C., found this conference, more than any other, to be formative in our development as policy faculty. What made the conference so special, particularly the ones held in Charleston? First, the conference was on a smaller scale than other social work education conferences. In smaller venues, most of us had breakfast and "happy hour" together, both good "bonding" experiences. The mixture of leaders in social work policy and relative novices created opportunities for good interchange, discussion, and even debate within a very collegial environment. It was an ideal venue to present ideas, get feedback, and gain new insights. As one of the "novices," I appreciated the opportunity to get to know some policy leaders, such as Bruce Jansson and Diana DiNitto, and form long lasting relationships. 


\section{Policy Practice Definitions and Textbooks}

Multiple authors have put forth definitions of policy practice and/or advocacy in social work practice. Jansson (1984) was one of the first social work policy scholars to differentiate policy practice from social work practice. More recently, he defined policy practice as "efforts to change policies in legislative, agency, and community settings, whether by establishing new policies, improving existing ones, or defeating policy initiatives of other people" (Jansson, 2005, p. 485). He places policy advocacy as part of policy practice. In their advocacy book, Schneider and Lester (2001) define advocacy, with roots in policy practice, as "the exclusive and mutual representation of a client(s) or a cause in a form, attempting to systematically influence decision making in an unjust or unresponsive system(s)" (p. 65). Cummins, Byers, and Pedrick (2011) define policy practice as "using social work skills to propose and change policy in order to achieve the goal of social and economic justice" (p. 2). For them, policy practice includes policy analysis, engagement with policy makers, and advocacy. They use the whole range of generalist social work practice skills to make policy more responsive to the demands of social justice. All of these definitions of policy practice embrace the core value of social work: working in the larger political context toward a more just society. Although political activism of this type has been a hallmark of the social work profession since its inception, historical accounts of such activities are rarely referenced under the more recent term policy practice, as noted above.

When I first started teaching in 1974, I was employed full-time as a social worker in a community agency working with families whose children who had developmental disabilities. I started teaching the history of social welfare policy course in a BSW program as a part-time faculty member. The texts we used back then included Romanyshyn (1971) and Gilbert and Specht (1974). Both paid little attention to issues of advocacy or social reform and focused primarily on federal policies. If advocacy was mentioned, it was usually in the context of case-based advocacy that the caseworker would use to secure services for a client.

In 1996 as the welfare reform act was being passed, I taught the second policy class, "Social Service Delivery Systems," in our BSW curriculum as a full-time faculty member. Most of the course objectives reflected knowledge acquisition and analysis skills. The last one stated: "An ability to employ a broad array of beginning policy practice skills, to initiate and attempt to influence the development of social policy within agencies and the broader community" (Personal, S352 Syllabus, 1996). Not precisely the policy practice we envision today but it seems to capture the essence of the transition from case-based advocacy to advocacy for policy change. We used Gilbert, Specht, and Terrell (1992) and Haynes and Mickelson (1991) as required texts. In the syllabus, I included a range of advocacy-related topics such as, how to write a letter to a legislator and how to monitor the legislation process. Reviewing that syllabus, I found that I devoted a full four weeks exclusively to the subject of policy practice, a new benchmark - at least for me.

The curriculum in our BSW program later evolved so that presently the first policy course covers history, current policy, and policy analysis and the second course reviews 
policy analysis but focuses primarily on all aspects of policy practice. We now assign a policy practice text written exclusively for policy practice courses. My sense, from talking with faculty associated with other social work programs, is that they too are experiencing similar developments within their respective policy sequences.

Policy textbooks have also undergone some dramatic transformations, changes that closely parallel and reflect the trends taking place within the policy curriculum as they respond to marketplace demand. Traditionally, most policy texts used a policy analysis framework to analyze important federal social welfare policies designed to meet basic human needs, including Gilbert and Specht (1974), DiNitto \& Dye (1983), Karger and Stoesz (1987), and Chambers (1993), and did not delve into policy practice. Some early pioneers started to hone in on policy practice skills such as Pierce (1984), McInnisDittrich (1994), Richan (1996), and Haynes and Mickelson (1997). Bruce Jansson (1990) merits special recognition in this discussion as authoring probably the first widely adopted textbook with a primary focus on policy practice. In the preface, he notes that since first writing about policy practice in his 1984 text:

I have become even more convinced that policy and funding realities of contemporary American society require social workers to become proactive participants in the shaping of policies - for ethical reasons (to try to redress inequalities and inequities), for professional reasons (to shape the policies that serve the needs of clients and oppressed populations), and for pragmatic reasons (to protect the prerogatives and interest of the social work profession) (Jansson, 1990, p. iv).

Both as a textbook writer and a social work educator with some prestige, his conviction and commitment to helping students learn specific policy practice skills, no doubt, was taken seriously by others. Policy practice started to be included in policy texts such as Segal \& Brzuzy (1998), Chapin (2007), and Ritter (2013). Other social work policy educators started to write texts that focused more completely on policy and advocacy skills such as Schneider and Lester (2001) and Rocha (2007). Now, with policy practice as a core competency, we see more textbooks with a primary focus on policy practice and advocacy skills, including Cummins, Byers, and Pedrick (2011), Hoefer (2013), and Jansson (2011). Many social work educators today are demanding 'competency-based' textbooks that will help equip students with the important practice skills needed to carry out effective policy practice.

In addition, The Social Policy Journal, edited by Rick Hoefer, appeared on the scene in 2002, raising the research profile for social policy in general and providing a publication opportunity for social policy researchers, including those conducting research in policy practice. I remember that Rick was an early supporter of ISP and attended many of the Policy Conferences.

\section{Ethical Basis for Policy Practice}

Interestingly enough, it so happens that in the 2008 revised version of the NASW Code of Ethics, policy practice was clearly mandated as one of social work's core principles: "Social workers challenge social injustice" (NASW, 2008). It would be 
virtually impossible to uphold that principle of social justice without following the ethical standard of social and political action identified below. The two certainly go hand in hand.

6.04 Social and Political Action (a) Social workers should engage in social and political action that seeks to ensure that all people have equal access to the resources, employment, services, and opportunities they require to meet their basic human needs and to develop fully. Social workers should be aware of the impact of the political arena on practice and should advocate for changes in policy and legislation to improve social conditions in order to meet basic human needs and promote social justice (NASW, 2008).

Social work, with its person and environment perspective, challenges us not only to help people and their families achieve the changes they want in their lives but also to work toward changing the environments within which they live to more readily achieve that goal of social and economic justice. As C. Wright Mills has so aptly noted, behind every private problem resides a broader public issue (Mills, 1963, 1967). As social workers, we commit to working at both the micro and macro levels in practice.

\section{Inclusion in EPAS}

Though a policy advocacy role for social workers was acknowledged in the 2001 EPAS, the explicit mention of policy practice is brief: "Analyze, formulate, and influence social policies" (CSWE, 2001, p. 7). And within the discussion of the Social Welfare Policy and Services component of the foundation curriculum, the development of policy practice skills is imbedded only in a much broader discussion of policy.

Programs provide content about the history of social work, the history and current structures of social welfare services, and the role of policy in service delivery, social work practice, and attainment of individual and social well-being. Course content provides students with knowledge and skills to understand major policies...; analyze organizational, local, state, national, and international issues...; analyze and apply the results of policy research...; understand and demonstrate policy practice skills in regard to economic, political, and organizational systems, and use them to influence, formulate, and advocate for policy consistent with social work values (italics added for emphasis); and identify... processes required to deliver social services (CSWE, 2001, pp. 9-10).

Some of us feared that policy practice skill development could be easily overlooked or minimized when it seemed to play such a minor role in the standards. As the 2008 EPAS was under development, we started to advocate for greater prominence for policy practice within social work education. After chairing a roundtable discussion and brainstorming session at the 2006 Policy Conference on ways to evaluate the policy practice curriculum for CSWE accreditation site visitors, I wrote a note to myself about a possible research project, "Is policy practice dependent on individual faculty or institutionalized in different programs and how would you know?" Many of us, who were both involved with ISP and the Policy Conferences, saw scant attention to policy practice within the policy course syllabi that we saw. We were concerned that inclusion of policy 
practice skills was too dependent on the individual faculty teaching the policy courses. We noted that some faculty teaching policy courses had little or no direct experience with advocacy efforts themselves. Without that experience, how could we expect them to engage students in policy practice in a passionate, empowering manner? It was a topic of discussion at meetings, lunches, and other informal encounters that we had together. Both ISP and the Policy Conferences, in bringing policy faculty together for multiple interactive opportunities, provided the synergistic effect of giving policy faculty a greater voice as a critical mass. As policy advocates, we knew how to "speak up."

I remember small, intense meetings at several conferences during the debate and discussion in the years of the development of the 2008 EPAS. Members of ISP wrote letters to the CSWE EPAS committee advocating for a specific and detailed statement on policy practice in the new EPAS. Bob Schneider remembers that about 150 comments/letters were submitted to the committee about all areas of the curriculum statement and, of that number, over 50 of them were from ISP members. As policy practitioners ourselves, we know the importance of letter writing campaigns. I remember my absolute joy when I first read the strong statement that the 2008 EPAS made about policy practice by identifying it as one of the core competencies.

From late 2007 into the spring of 2008, CSWE posted online and circulated drafts of the new EPAS, with multiple (though some, at the time, suggested there were not enough) opportunities for CSWE members to provide feedback, both at national social work education meetings and in written submitted comments. In multiple forums, there was lively discussion and debate on both the content of the EPAS and the process. Despite the controversy, the ultimate shift to competencies in EPAS brought social work education into a position of leadership within the national movement in higher education toward competency-based education and assessment (Williams, 2007). Those ten core competencies included one focused on policy practice: "Educational Policy 2.1.8Engage in policy practice to advance social and economic well-being and to deliver effective social work services" (CSWE, 2008, p. 6).

\section{Next Steps - Moving the Agenda Forward}

With policy practice now institutionalized as a core competency, the question becomes how to move the policy practice agenda forward. Many of us who were involved in the effort to achieve this goal over recent years have retired or are nearing retirement. Though some of us may remain engaged in social work education issues, we will not have the same clout that comes with occupying leadership positions in social work organizations and programs. New leadership is emerging with new authors of textbooks, new faculty teaching policy practice, and new leaders in partner organizations such as NASW. In our recent phone conversation, Bob Schneider and I discussed some possible next steps so that policy practice remains central and essential to social work practice.

1. For ISP, we need to maintain a focus on state level policy as devolution has continued since 1996. Current hot legislative and administrative issues at the state level include Medicaid expansion under the Affordable Care Act, marriage 
equality, immigration, voting rights, mental health, and gun control. While many of these issues will undoubtedly change or evolve over time, the need for the skills required to influence the direction of such changes will remain constant. Social work faculty can provide advocacy leadership in the states and help get students involved to develop policy practice skills. Helping students and practitioners use social media, both to provide information and to do grassroots organizing, will help ISP move beyond its web presence. While ISP has a Facebook page, it is in the early stages of development and needs more "friends" and further development. ISP must find more institutional support for the contests as they provide powerful experiential learning opportunities for students as well as a tangible recognition for substantive advancements in the field of policy practice. Developing new videos and other more current resources will be important for faculty who are always looking for ways to support their classroom teaching.

2. Providing opportunities for policy practitioners and policy educators to come together continues to be important for our future development. At the time of this writing, Sunny Harris Rome, Jessica Ritter, Stacey Borasky, and I are planning Policy Conference 2.0, in Austin, TX from May 29-31, 2014, with the theme, Energizing for Activism: Recommitting to Policy Change. The conference will both revive the Policy Conference, a pivotal experience in the development of many current policy practice educators, and help us set the agenda for the future in policy practice as we engage new policy faculty as well. The call for papers is out and we anticipate a strong response with the growing interest in policy practice.

3. A new generation of student activists with front-line experience in advocacy through the Occupy Movement and other social actions will come into social work programs. As they pursue their social work careers, we hope they will continue to maintain that activist orientation within the profession and within social work education, if that is the direction they follow. Preparing them with a wide range of policy practice skills will be important as we and they move forward.

4. Both social work practitioners and faculty need to identify those to whom we will pass the advocacy baton. Who will organize the future Lobby Days, whatever form they take? Who will testify at hearings and mount the letter writing campaigns on important social justice issues? Who will do the door-to-door knocking (both virtual and situated in communities) to engage the grassroots in voting and other acts of civic participation? The role of current faculty is to inspire their students to engage in policy practice and develop the necessary skills for successful social change. We will always need social workers with advocacy skills since, to quote Frederick Douglass (1857), "Power concedes nothing without a demand. It never did and it never will." 


\section{Conclusion}

Reflecting on this evolutionary journey toward a renewed emphasis on policy practice and the roles that so many played in that process reinforces for me the power of both passion and hard work in policy practice itself. At the time of this writing, I am working with other advocates in Indiana to defeat a proposal that would amend our state constitution to include a ban on marriage that is not between a man and a woman, or any other legal status that would grant rights and privileges "substantially similar" to those granted by marriage. Passion and hard work will ultimately result in the defeat of this discriminatory amendment, even if it is passed and has to be challenged in the courts. Passion and hard work will pay off in achieving social justice in the end; that I know from my own experience. Through the passion and hard work of many social workers and social work educators, we now have a mandate to educate students in policy practice so that they can continue this fight for social justice long after you and I are gone. I have a sense that we are on the right path as we move forward.

\section{References}

Abramovitz, M. (1998). Social work and social reform: An arena of struggle. Social Work, 43, 512-526.

Byers, K., \& Pirog, M. (2003). Local government responses to welfare reform. Public Budgeting and Finance, 23, 86-107

Chambers, D. (1993). Social policy and social programs: A method for the practical public policy analyst. Boston, MA: Allyn \& Bacon.

Chapin, R. (2007). Social policy for effective practice: A strengths approach. Boston, MA: McGraw Hill.

Council on Social Work Education (CSWE). (2001. Revised June 2003 and October 2004.). Educational policy and accreditation standards. Retrieved from http://www.cswe.org/File.aspx?id=14115

Council on Social Work Education (CSWE). (2008, Revised March 27, 2010 / Updated August 2012). Educational policy and accreditation standards. Retrieved from http://www.cswe.org/File.aspx?id=41861

Cummins, L., Byers, K., \& Pedrick, L. (2011). Policy practice for social workers: New strategies for a new era (Updated edition). Boston, MA: Pearson/Allyn \& Bacon.

DiNitto, D. M., \& Dye, T. R. (1983). Social welfare: Politics and public policy. Englewood Cliffs, NJ: Prentice-Hall.

Douglass, F. (1857). Two Speeches by Frederick Douglass... (Rochester, 1857) Retrieved from http://www.blackpast.org/1857-frederick-douglass-if-there-nostruggle-there-no-progress\#sthash.ApnUt0if.dpuf

Gilbert, N., \& Specht, H. (1974). Dimensions of social welfare policy. Englewood Cliffs, NJ: Prentice Hall. 
Gilbert, N., Specht, H., \& Terrell, P. (1992). Dimensions of social welfare policy $\left(6^{\text {th }} \mathrm{ed}\right.$.). Englewood Cliffs, NJ: Prentice Hall.

Haynes, K., \& Michelson, J. (1997). Affecting change: Social workers in the political arena. Needham Heights, MA: Allyn \& Bacon.

Hoefer, R. (Ed.). (2013). New horizons for policy practice. New York, NY: Routledge.

Jansson, B. S. (1984). Theory and practice of social welfare policy: Analysis, processes, and current issues. Belmont, CA: Wadsworth.

Jansson, B. S. (1990). Social policy: From theory to policy practice. Pacific Grove, CA: Brooks/Cole.

Jansson, B. S. (2005). The reluctant welfare state: American social welfare policies Past, present, and future ( $5^{\text {th }}$ ed.). Belmont, CA: Brooks/Cole.

Jansson, B. S. (2011). Becoming an effective policy advocate: From policy practice to social justice $\left(6^{\text {th }}\right.$ ed.). Belmont, CA: Brooks/Cole.

Karger, H., \& Hernández, M. (2004). The decline of the public intellectual in social work. Journal of Sociology and Social Welfare, 31, 51-68.

Karger, H., \& Stoesz, D. (1987). American social welfare policy: A pluralist approach. Boston, MA: Allyn \& Bacon.

Larrison, C., Nackerud, L., Lane-Crea, L., \& Robinson-Dooley, V. (2005). The relationship between the Personal Responsibility and Work Opportunity Reconciliation Act of 1996 and innovative welfare practices on a local level. Journal of Human Behavior in the Social Environment, 12, 205-219.

Lens, V., \& Gibelman, M. (2000). Advocacy be not forsaken! Retrospective lessons from welfare reform. Families in Society: The Journal of Contemporary Human Services, 81, 611-620.

Long, D. (2000). Welfare reform: A social work perspective for assessing success. Journal of Sociology \& Social Welfare, 27, 61-78.

McInnis-Dittrich, K. (1994). Integrating social welfare policy and social work practice. Pacific Grove, CA: Brooks/Cole.

Mills, C. Wright. (1963, 1967). Power, politics and people. The collective essays of C. Wright Mills (Edited by Irving H. Horowitz). New York, NY: Oxford University Press.

Mills, F. (1996). The ideology of welfare reform: Deconstructing stigma. Social Work, 41, 391-395.

NASW Foundation. (n.d.). NASW Foundation national programs: NASW Social Work Pioneers ${ }^{\circledR}$, Howard Gustafson. Retrieved from http://www.naswfoundation.org/pioneers/g/gustafson.html 
National Association of Social Workers (NASW). (2008). NASW Code of Ethics.

Retrieved from http://www.socialworkers.org/pubs/code/code.asp

National Conference on Social Welfare. (1969). The social welfare forum, 1969: Official proceedings, $96^{\text {th }}$ Annual Forum National Conference on Social Welfare, New York, New York, May 25-May 29, 1969. New York, NY: Columbia University Press.

Pierce, D. (1984). Policy for the social work practitioner. New York, NY: Longman.

Purpose. (1997). Influencing State Policy. Retrieved from http://www.statepolicy.org/About\%20Us/Purpose.html

Richan, W. (1996). Lobbying for social change ( $2^{\text {nd }}$ ed.). New York, NY: Hayworth.

Ritter, J. (2013). Social work policy practice: Changing our community, nation, and the world. Upper Saddle River, NJ: Pearson.

Rocha, C. (2007). Essentials of social work policy practice. Hoboken, NJ: John Wiley \& Sons.

Romanyshyn, J. (1971). Social welfare: Charity to justice. With the assistance of Annie L. Romanyshyn. New York, NY: Random House.

Schneider, R. (2002). Influencing "state" policy: Social work arena for the $21^{\text {st }}$ century. The Social Policy Journal, 1, 113-116.

Schneider, R. (2003). Policy Advocacy Challenge 3.3: A social work professor organizes a national committee to advocate for welfare recipients. In B. Jansson, Becoming an effective policy advocate: From policy practice to social justice ( $4^{\text {th }}$ ed., pp. 95-98). Pacific Grove, CA: Brooks Cole.

Schneider, R. (2004). Educating for policy practice: ISP mobilizes resources to put students and faculty in the action of change (2004). Social Work Education Reporter, Winter, 25-27.

Schneider, R., \& Lester, L. (2001). Social work advocacy: A new framework for action. Belmont, CA: Wadsworth/Thomson Learning.

Schneider, R., \& Netting, E. (1999). Influencing social policy in a time of devolution: Upholding social work's great tradition. Social Work, 44, 349-357.

Segal, E., \& Brzuzy, S. (1998). Social welfare policy, programs, and practice. Itasca, IL: Peacock.

Specht, H., \& Courtney, M. (1994). Unfaithful angels: How social work has abandoned its mission. New York, NY: The Free Press.

Stoesz, D. (1999). Ideological nostalgia, intellectual narcosis. In G. R. Lowe \& P. N. Reid (Eds.), The professionalization of poverty: Social work and the poor in the twentieth century (pp.141-160). New York, NY: Aldine de Gruyter.

"Students seek state clout." (1997). NASW News, 42. 
Swigonski, M. (1996). Women, poverty, and welfare reform: A challenge to social workers. Afflia, 11, 95-110.

The Policy Conference for Social Work Education and Practice. (2002). Columbia, SC: University of South Carolina.

Williams, C. (2007). Editor's prerogative. BPD Update Online. Retrieved October 22, 2007, from http://bpdupdateonline.org/fall2007/id13.html.

Wolk, J. (1981). Are social workers politically active? Social Work, 26, 4, 283-288.

\section{Author note}

Address correspondence to: Katherine V. Byers, Ph.D., Indiana University School of Social Work, 1127 Atwater, Bloomington, IN 47405. Email: kvbyers@,indiana.edu

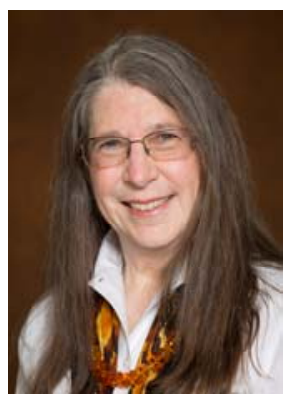

Katharine V. Byers, Ph.D., Associate Professor, directs the Bloomington BSW Program, Indiana University School of Social Work and chairs Influencing State Policy. With a BA from Wellesley College and MSW from the Heller School at Brandeis University, she had 10 years of practice experience, primarily with children with disabilities, before earning her Ph.D. from Indiana University. She teaches BSW policy and macro practice courses. She has researched the impact of welfare reform in Indiana and student activism. In 2004, she received the NASW Indiana Distinguished Chapter Service Award for creating the first Legislative Education and Advocacy Day (LEAD) in Indiana.

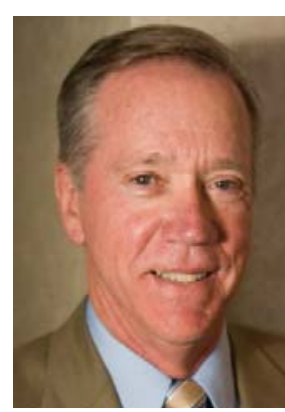

Dr. Robert (Bob) L. Schneider is Professor Emeritus at the School of Social Work at Virginia Commonwealth University. He earned his MSW and PhD degrees in social work from Tulane University. Bob was a Delegate to the 1981 White House Conference on Aging, became a Fellow in the Gerontological Society of America, and was co-founder and first President of the Association for Gerontology Education in Social Work. He served for more than a decade on the Governor's Advisory Board to the Virginia Department for the Aging. In 1997, Bob founded Influencing State Policy (ISP), a group that promotes inclusion of policy advocacy at the state level into the curricula of all programs of social work education nationally, and served as its Chair for 11 years. 